\title{
MALALA DEBATE O FUNDAMENTALISMO RELIGIOSO
}

Neste nono número da Revista Malala dedicado ao fundamentalismo religioso tivemos muitas contribuições que nos convidam a repensar as várias definições para o termo - tanto como conceito do campo religioso como comportamento político. Trata-se tanto de um conceito histórico como de um fato sociológico de nosso tempo. Faz-se presente a ideia de retornar à mensagem "original" de uma religião e de voltar à teologia, aos valores e aos modos de religiosidade da (suposta) comunidade pristina de seus primeiros crentes. Além de contribuições analisando facetas ou aspectos de islamismos em várias situações geográficas, históricas e sociais, a Revista abre suas colunas às discussões sobre o leque mais amplo de fundamentalismos, incluindo todos que estiverem relacionados ao Oriente Médio e ao Mundo Muçulmano lato sensu, assim como as reações ao islã em outras religiões e regiões (como, por exemplo, entre cristãos no ocidente).

Excepcionalmente neste número oferecemos ao leitor três entrevistas. Ariel Finguerut conversou com Christian Picciolini, autor e articulador anti-fascista, que conta parte de sua trajetória de militante neonazista na juventude em Chicago até seu atual trabalho à frente de sua ONG Life After Hate. Alí, Picciolini propõe-se a ouvir e dialogar com pessoas que buscam caminhos para sair de grupos extremistas e a desenvolver estratégias para enfrentar a radicalização política. Beatriz Buarque conversou com Shahid Butt, de origem paquistanesa, residindo em Londres. A conversa destaca estratégias de recrutamento de jihadistas em regiões até hoje sensíveis para o Mundo Muçulmano como Bósnia, Afeganistão e Iêmen. E fechando a sessão de entrevistas, Peter Demant conversou a convite do Centro Cultural Brasil-Turquia com Fethullah Gülen, intelectual de grande influência no islã. 0 líder espiritual islâmico turco responde, de seu exílio nos EUA, a algumas perguntas sobre a Turquia, o islã e seu movimento político-espiritual.

Na busca para entender a radicalização e mobilização de movimentos fundamentalistas e jihadistas no islã - como por exemplo nas fileiras do Estado Islâmico do Iraque e do Levante (ISIS na sigla em inglês) - Victor Begeres Bisneto dialoga com autores da literatura russa clássica, debatendo o niilismo e levantando ideias próximas ao existencialismo para entender o fenômeno. João Gallegos Fiuza discute o apelo e impacto fundamentalista sobre os direitos sociais e políticos das mulheres muçulmanas. Peter Demant apresenta em ensaio as ideias de an-Na'im, Irshad Manji e Maajid Nawaz, no contexto de reformistas contra leituras fundamentalistas no islã. 0 ensaio de Priscila Lima Pereira e Rachel Campos faz uma radiografia do grupo terrorista Tehrik-i-Taliban Pakistan, cuja ideologia religiosa e influência persistem entre a juventude de áreas tribais do Paquistão.

Na sessão de resenhas, Jose Antônio Lima debate as ideias apresentadas por Graeme Wood, cuja obra debate o Estado islâmico em seus aspectos teológicos e ideológicos. Ariel Finguerut estabelece pontes entre dois fundamentalismos, o islâmico e o judaico, discutindo dois documentários: um que foca no Paquistão, numa Madrasa voltada para educação de jovens e crianças, e outro cujo foco dirige-se ao judaísmo hassídico nos EUA, em meio às vicissitudes de pertencimento, aceitação, identidade e sociabilidade.

Em artigos de fluxo continuo apresentamos neste número um vasto panorama de trabalhos interdisciplinares: Monique Sochaczewski analisa a república turca em três momentos e uma profusão de golpes militares, cobrindo o período de 1923 à 2002 - de 
Atatürk a Erdoğan. Em seu relato de pesquisa Stéphane Dias discute os conceitos de agência e racionalidade comunicativas aplicados ao cenário diplomático-político de mediação de conflitos, concentrando-se nos diálogos de paz israelo-palestinos a partir da estrutura dialógica e de seus agentes. 0 relato de campo deste número fica a cargo de Augusto Veloso Leão e Jameson V. M. da Silva, que concedem importantes registros dos últimos dias antes do desmantelamento do acampamento de imigrantes e refugiados de Calais, ou "Selva de Calais", no norte da França.

Boa Leitura!

São Paulo, 20 de Julho de 2018

Peter Robert Demant

Editor-chefe da Revista Malala

Ariel Finguerut

Membro do Conselho Científico da Revista Malala 